\title{
Separation of Aluminum from More Noble Elements in an Electrolysis Cell with Side-by-Side Geometry
}

\begin{abstract}
ASBJØRN SOLHEIM, OLE S. KJOS, HENRIK GUDBRANDSEN, and EGIL SKYBAKMOEN

Currently, recycled metal is diluted with primary metal to keep the concentration of alloying elements within specification. This will be more difficult in the future, when a larger proportion of the metal is made from scrap. Particularly, there is a need for a process that can remove elements more noble than aluminum from the scrap metal. While electrolytic refining in a three-layer cell (the Hoopes process) is a possibility; the present paper presents a simpler and more flexible electrolysis cell where the anode metal (alloy) and the cathode metal (purified metal) are placed side-by-side. The principle was demonstrated in a laboratory cell. The current efficiency was above $80 \mathrm{pct}$ and the specific energy consumption was about $7 \mathrm{kWh} / \mathrm{kg} \mathrm{Al}$. The refining effect was very good, e.g., the copper content in the $7 \mathrm{xxx}$ alloy used was reduced from $2.1 \mathrm{wt}$ pct to less than $20 \mathrm{ppm}$. An industrial version of the cell used in the present work is suggested. The principles and design are generic and can be used for other purposes than recycling aluminum.
\end{abstract}

https://doi.org/10.1007/s11663-021-02122-9

(C) The Author(s) 2021

\section{INTRODUCTION}

PRODUCTION of primary aluminum metal is extremely energy intensive (in average, $13.35 \mathrm{kWh} \mathrm{DC} /$ $\mathrm{kg} \mathrm{Al}$ in $\left.2018^{[1]}\right)$. Recycling of scrap aluminum requires only about 5 pct of the original energy, however. ${ }^{[2]}$ Recycled metal, including old scrap and manufacturing scrap, accounted for 31.6 pct of the total production worldwide in $2017,{ }^{[3]}$ and it was 53.6 pct in North America. Of the $24.7 \mathrm{Mt}$ of end-of-life products, $17.9 \mathrm{Mt}$ (58.9 pct) was recycled. Recycling is assumed to become even more important in the future circular economy.

The current processes for recycling of metal involves collection and sorting of scrap, decoating, and melting. Sorting is a very important step because some aluminum scrap contains alloying elements that are not easily removed, and thereby accumulate in the produced metal. While elements less noble than aluminum can easily be taken away by oxidation, there exist or, there are effective methods for removing noble alloying elements. This is not a severe problem currently, because special alloys can be treated separately by making similar alloys. An example is the copper-containing 2xxx

ASBJûRN SOLHEIM, OLE S. KJOS, HENRIK GUDBRANDSEN, and EGIL SKYBAKMOEN are with the SINTEF Industry, P.O. Box 4760 Torgarden, 7645 Trondheim, Norway. Contact-email: asbjorn.solheim@sintef.no

Manuscript submitted October 17, 2020; accepted February 15, 2021.

Article published online March 25, 2021. alloys ("duralumin") which are much used in the aircraft industry. Moreover, the scrap will be "thinned out" with primary metal. However, the situation will become more difficult in the future, when a larger proportion of the metal is made from scrap.

Composite alloys represent a special problem. An example is heat exchangers used in cars and refrigerators, where the individual parts (tubes, fins, etc.) are made with different alloys ${ }^{[4]}$ that are welded or soldered together in such a way that they cannot be readily disassembled. By melting all together, the resulting alloy is not necessarily useful.

The purpose of the present work was to develop a process for removing impurities from "difficult" scrap aluminum-containing noble elements, aiming at producing aluminum metal with purity comparable with primary aluminum, but produced with significantly lower specific energy than primary metal. Experiments using the well-known three-layer process used for refining of aluminum were reported earlier ${ }^{[5]}$ while the present paper deals with results obtained in an electrolysis cell with "side-by-side" geometry. The approach was to perform a rather low budget screening of different ideas concerning cell construction and electrolyte composition, and the cells were largely produced from parts already present in our laboratory. Unfortunately, the budget did not allow for a more comprehensive study including fine-tuning of promising electrolyte candidates or assessment of reproducibility. The cell can 
be used for other purposes as well, such as refining of rare earth metals or enrichment of alloys containing a non-noble element.

\section{THEORY}

Elements less noble than aluminum can be removed by adding an aluminum salt, which is routinely being used for treating primary metal (fluxing):

$$
x M+\mathrm{AlF}_{3}=x \mathrm{MF}_{3 / x}+\mathrm{Al}
$$

The method cannot be used for removing alloying elements more noble than aluminum, since the thermodynamics requires that they remain in their elemental form. However, it is possible to remove the aluminum from the alloy electrochemically.

In electrorefining, aluminum is dissolved anodically into the electrolyte (bath), leaving the more noble elements behind. Pure aluminum is deposited at the cathode, while non-noble elements remain in the electrolyte.

The refining cell patented by Hoopes nearly 100 years ago ${ }^{[7]}$ is still in use. This is a three-layer process where the anode metal (Al-Cu alloy) and the cathode metal (refined Al) are separated by the electrolyte. The arrangement entails strict restrictions concerning the densities, which limits the choice of electrolyte composition. By placing the anode metal and the refined metal side-by-side in separate compartments, the density restrictions are relieved. The cell principles are illustrated in Figure 1.

Since the non-noble elements end up in the electrolyte, it will be advantageous to remove those before treatment (Eq. [1]). Examples are the alkalis and the alkaline earth metals. It can be expected that the refining effect is good for noble elements with reduction potentials far from aluminum, such as $\mathrm{Cu}, \mathrm{Co}, \mathrm{Fe}$, and $\mathrm{Pb}$. Copper is probably the most valuable of the noble elements used in aluminum alloys. There will probably be a "gray zone" for elements with reduction potentials close to aluminum, where the refining effect will depend on the concentration.

The electrode- and cell reactions are:

Anode reaction:

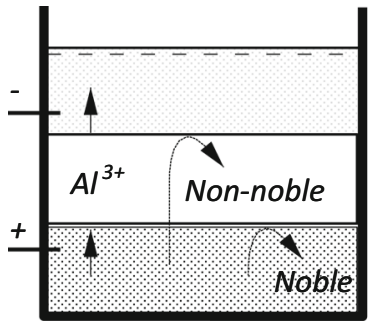

(a)

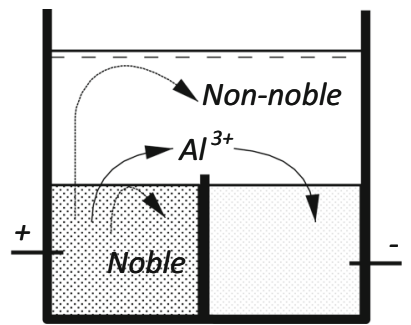

(b)
Fig. 1-Principles for electrorefining in a three-layer cell $(a)$ and in a side-by-side cell (b). Non-noble elements (as compared with $\mathrm{Al}$ ) are oxidized into the electrolyte, but they are rejected at the cathode. Noble elements will not be oxidized if less noble substances are present.

$$
\mathrm{Al}(a)+3 \mathrm{MX}(a) \rightarrow \mathrm{AlX}_{3}(a)+3 M^{+}+3 e
$$

Cathode reaction:

$$
\mathrm{AlX}_{3}(c)+3 e+M^{+} \rightarrow \mathrm{Al}(c)+3 \mathrm{MX}(c)
$$

Cell reaction:

$$
\begin{aligned}
& \mathrm{Al}(a)+3 \mathrm{MX}(a)+\mathrm{AlX}_{3}(c) \\
& \quad \rightarrow \mathrm{Al}(c)+3 \mathrm{MX}(c)+\mathrm{AlX}_{3}(a)
\end{aligned}
$$

where $\mathrm{M}$ is an alkali element and $\mathrm{X}$ is a halide. The species on each side of Eq. [4] are the same, so the standard voltage for the cell reaction is zero, while the reversible voltage only depends on the activities of aluminum.

A large proportion of the current in the electrolyte is probably transported by the alkali ions, depending on the electrolyte composition (e.g., the transport number for $\mathrm{Na}^{+}$in molten cryolite $\left(\mathrm{Na}_{3} \mathrm{AlF}_{6}\right)$ is $\left.0.99^{[6]}\right)$. This means that the aluminum-containing species are transported by diffusion and convection, so there will be concentration gradients close to the electrodes. The reactions are illustrated in Figure 2.

By analogy with the cathode reaction in the HallHéroult process for making primary aluminum, it is probable that the main part of the electrode overvoltage is due to the concentration differences between the bulk electrolyte and the electrode surfaces. The concentration overvoltages can be expressed by

$$
\begin{array}{r}
\eta_{c}=\frac{\mathrm{RT}}{3 F} \cdot \ln \left(\frac{a_{\mathrm{AlX}_{3}(c)} \cdot a_{\mathrm{MX}(\infty)}^{3}}{a_{\mathrm{AlX}_{3}(\infty)} \cdot a_{\mathrm{MX}(c)}^{3}}\right) \text { and } \\
\eta_{a}=\frac{\mathrm{RT}}{3 F} \cdot \ln \left(\frac{a_{\mathrm{AlX}_{3}(a)} \cdot a_{\mathrm{MX}(\infty)}^{3}}{a_{\mathrm{AlX}_{3}(\infty)} \cdot a_{\mathrm{MX}(a)}^{3}}\right)
\end{array}
$$

\section{EXPERIMENTAL}

The laboratory electrolysis cell consisted of a graphite crucible lined with a sinter corundum tube. A sinter corundum crucible was placed at the center. The anode alloy was pre-shaped at placed in the annulus between the inner crucible and the lining, whereas a small amount of pure aluminum was placed in the inner crucible. Electrical contact was made to the graphite crucible (anode) by means of a steel rod. A titanium

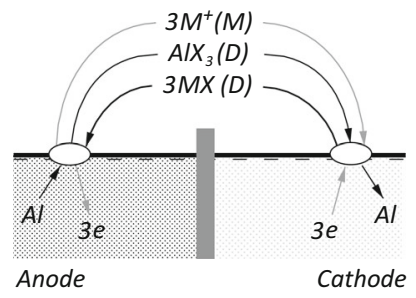

Fig. 2-Schematic illustration of the electrode processes. M: Migration, D: Diffusion. 
diboride rod served as cathode together with the metal in the inner crucible. The cell was placed in a vertical-tube laboratory furnace and flushed with dry argon. The aluminum fluoride used was produced in our own laboratory by vacuum sublimation of commercial grade aluminum fluoride containing about $2 \mathrm{wt}$ pct alumina, while the other chemicals were of p.a. quality. The powders were mixed manually and melted in the cell. The furnace was heated during 3 hours and the system was allowed to equilibriate for 1.5 hours before the experiment was started.

Four successful experiments (A-D) were conducted. Experiments $\mathrm{C}$ and $\mathrm{D}$ took place in a slightly larger cell than the one used in $\mathrm{A}$ and $\mathrm{B}$, which made it possible to accommodate an aluminum reference electrode. Electrolysis was performed for several hours, and the current efficiency was determined by weighting the purified metal produced at the cathode. Current, voltages, and temperature were logged each 5 seconds. The cell used in experiments $\mathrm{C}$ and $\mathrm{D}$ is sketched in Figure 3. The nominal anode- and cathode areas were 45.3 and 54.2 $\mathrm{cm}^{2}$, respectively.

The electrolyte composition and temperature varied between the experiments, and the data are shown in Table I in the results section below. The anode metal consisted of a 7xxx series alloy with $\mathrm{Zn}, \mathrm{Mg}$, and $\mathrm{Cu}$ as the main alloying elements. The exact analysis is given in Table II in the results section.

\section{RESULTS}

\section{A. Cell Performance}

The electrolyte composition, temperature, and recorded current efficiency for the four experiments are shown in Table I.

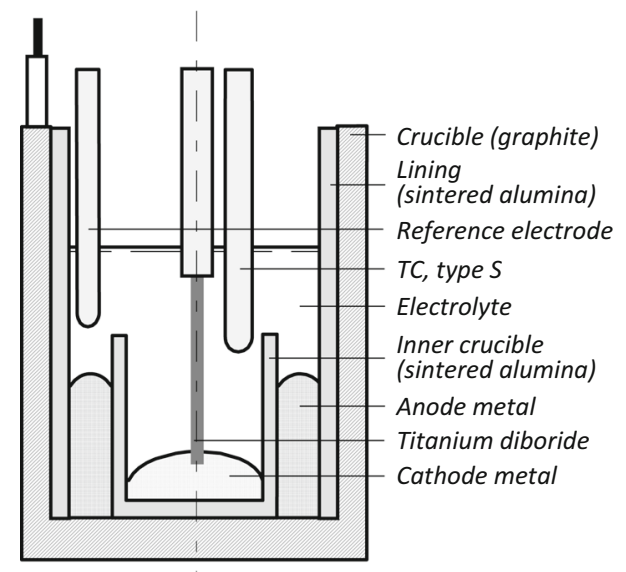

Fig. 3-Laboratory cell for separation of aluminum from nobler elements.
Experiment A was run for 4 hours 41 minutes before it was stopped due to increasing cell voltage. The current efficiency was comparably low. This may be due to the relatively high temperature, or the fact that the electrolyte contained small aluminum droplets after the experiment, which made it difficult to collect all the produced metal.

Experiment B utilized a low-melting mixed chloride and fluoride electrolyte. The experiment was run for 6 hours until it was interrupted by a broken anode current contact (the graphite crucible was worn by air oxidation). The cell voltage was low, around $2 \mathrm{~V}$. The current efficiency was difficult to assess due to some droplet formation, but it appeared to be acceptable.

Experiments $\mathrm{C}$ and $\mathrm{D}$ were run with mixed chloride-fluoride electrolytes. The $\mathrm{MX} / \mathrm{AlF}_{3}$ molar ratio was chosen to be about 3 ("cryolite composition"), which is close to maxima in electrolyte density as well as liquidus temperature. The reason for this choice is elaborated in the discussion below. Experiment $\mathrm{C}$ was run for about 8.5 hours. During the last 3.5 hours, the cell voltage was stable and about $2 \mathrm{~V}$ at $25 \mathrm{~A}$ (current densities 0.55 and $0.46 \mathrm{~A} \mathrm{~cm}^{-2}$ at the anode and the cathode, respectively). $2 \mathrm{~V}$ and 84 pet current efficiency gives $7.09 \mathrm{kWh} / \mathrm{kg} \mathrm{Al}$, which is about half of the energy used for making primary aluminum.

The electrolyte in experiment D probably contained too much $\mathrm{LiCl}$. It appeared that the electrolyte wetted the solid surfaces extremely well, so the electrolyte could be found underneath the metal in the inner crucible, between the lining and the inner wall of the graphite crucible, and underneath the anode metal. The cathode metal did not collect properly to form a solid lump, so the current efficiency could not be determined.

The voltage-current course in experiment $\mathrm{C}$ is shown in Figure 4. As can be observed, there was an increase in the anode voltage at the beginning of the experiment, but the voltage decreased again after 2 to 3 hours. A similar pattern was observed also in experiment D. The reason for this behavior has not been clarified.

\section{B. Refining Effect}

Samples of the metal collected from the inner crucible were taken by drilling out boring chips that were analyzed with ICP. The metal analyses are listed in Table II together with the analysis of the anode metal. As can be observed, the refining effect is very good for all elements, except that there was an unexplainable increase in the silicon concentration. Although silicon could be one of the "gray zone" elements with low refining effect, none of the materials used in the cell contained appreciable amounts of silicon. The boron concentration is also higher than in the anode metal, but boron is usually present in nearly all refractory materials. The produced metal contains lithium stemming from the electrolyte. Lithium is generally unwanted in aluminum, at least in metal intended for aluminum foil production. While it can be removed by fluxing, it is more difficult to remove than other non-noble elements. 
Table I. Electrolyte Compositions (mol pct), Temperature (Average and Standard Deviation for the Last 2/3 of the Experiment), and Current Efficiency (CE)

\begin{tabular}{lrlllllll}
\hline No. & $\mathrm{AlF}_{3}$ & $\mathrm{NaF}$ & $\mathrm{LiF}$ & $\mathrm{NaCl}$ & $\mathrm{LiCl}$ & $\mathrm{Temp} .\left[{ }^{\circ} \mathrm{C}\right]$ & $\mathrm{CE}[\mathrm{pct}]$ & $\mathrm{Comment}$ \\
\hline A & 28.1 & 46.9 & 25.0 & - & - & $867 \pm 4$ & 42.3 & 1 \\
B & 9.4 & - & - & 40.7 & 49.9 & $683 \pm 4$ & $\approx 80$ & -12 \\
C & 24.8 & - & - & 31.6 & 43.6 & $776 \pm 2$ & 83.9 & N/A \\
D & 25.0 & - & - & - & 75.0 & $747 \pm 6$ & 3 \\
\hline
\end{tabular}

Comment 1. High cell voltage, increasing during experiment, Comment 2. Low and stable cell voltage, Comment 3. Problems related to wetting and creeping of electrolyte.

Table II. Elements Present in the Anode Alloy and in the Cathode Metal from Experiments A-D (ppmw) as Analyzed with ICP

\begin{tabular}{lllllllll}
\hline & $\mathrm{Si}$ & $\mathrm{Fe}$ & $\mathrm{Cu}$ & $\mathrm{Mn}$ & $\mathrm{Mg}$ & $\mathrm{Zn}$ & $\mathrm{Ti}$ & $\mathrm{B}$ \\
\hline Anode & 69 & 1265 & 21000 & 243 & 34000 & 89000 & 292 & $<10$ \\
A & 1769 & 128 & 20 & 5 & 22 & 20 & 144 & 45 \\
$\mathrm{~B}$ & 41 & 41 & 16 & $<5$ & 411 & 30 & $<5$ & $<20$ \\
$\mathrm{C}$ & 239 & 65 & 9 & 10 & $<5$ & 122 & 45 & 35 \\
$\mathrm{D}$ & 379 & 60 & 12 & 11 & 0 & 205 & 15 & 79 \\
\hline
\end{tabular}

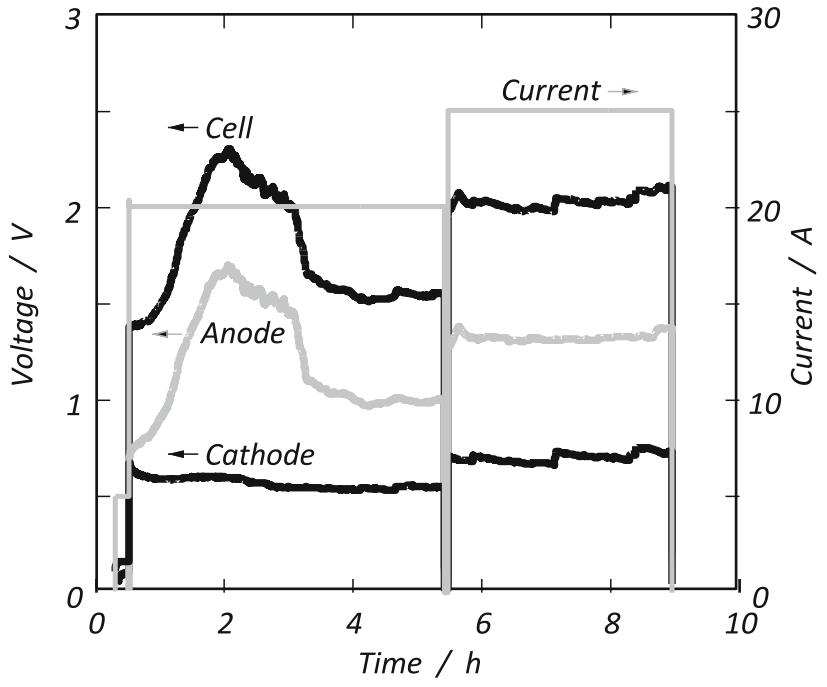

Fig. 4 - Cell voltage, voltage between anode and reference electrode, voltage between cathode and reference, and current as a function of time in experiment $\mathrm{C}$.

\section{DISCUSSION}

\section{A. Industrial Feasibility}

The goal was to demonstrate metal production from scrap with purity comparable with primary aluminum. This expectation was more than fulfilled. The laboratory cells used in the present work were not at all optimized with respect to cell voltage or current efficiency, and there is reason to believe that much better performances can be achieved.

A possible arrangement for an industrial version of the side-by-side cell is sketched in Figure 5. The anode alloy and the cathode metal are located in channels separated by an insulating material (sintered alumina will be possible if the electrolyte has low enough alumina

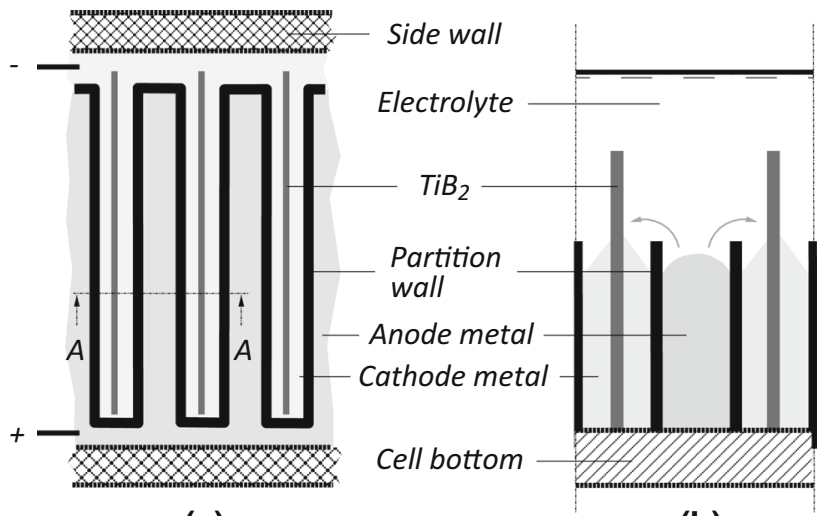

(a)

(b)

Fig. 5-Schematic illustration of possible arrangement for industrial version of a side-by-side cell for recovery of scrap aluminum-containing noble elements. (a) Cell seen from above (b) Section A-A. The arrows in (b) indicate the current path.

solubility). The current may be supplied by electrodes placed in the peripheral channels. The cathode metal can be removed by a simple spillway. The anode metal can be added as a granulate or in the liquid state. $\mathrm{TiB}_{2}$ slabs placed in the cathode channels are not strictly necessary, but they will serve to reduce the ohmic resistance through the electrolyte.

\section{B. Electrolyte Composition}

The electrolyte composition changes near the electrodes, due to the transport processes illustrated in Figure 2. The electrolyte near the cathode will be more basic (higher $\mathrm{MX} / \mathrm{AlX}_{3}$ ratio), while the composition is displaced in the acid direction at the anode. The concentration differences will increase if the electrolyte is quiescent, which might be the case in this process since 


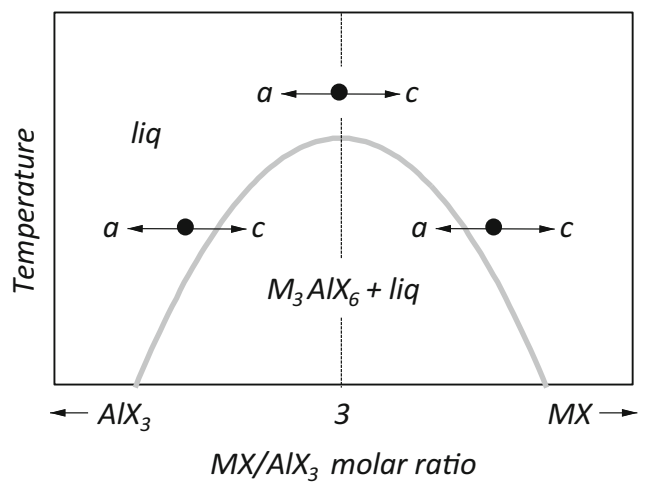

(a)

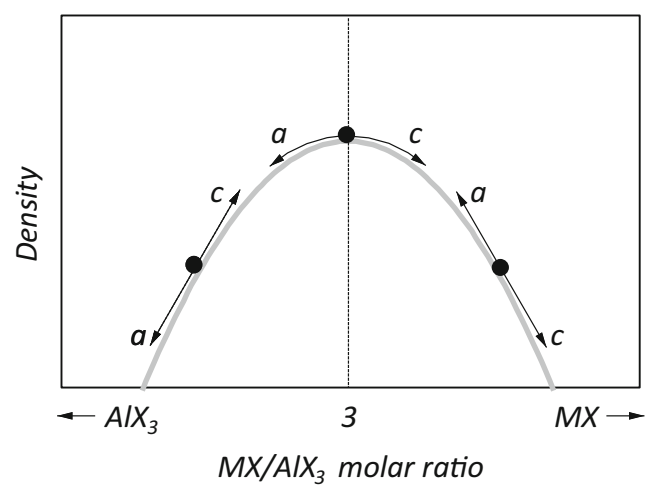

(b)

Fig. 6-Schematic diagrams of liquidus temperature $(a)$ and density $(b)$ of the electrolyte. The arrows indicate changes near the electrodes resulting from transport processes (see the text for explanations).

there is no convection due to gas bubbles (magnetohydrodynamic flow may occur, depending on the amperage).

The salt mixtures involved make complexes, e.g., $\mathrm{AlX}_{6}^{3-}$. In fluoride melts, the liquidus temperature as well as the density show maxima close to the cryolite compositions $\left.\left(\mathrm{Na}_{3} \mathrm{AlF}_{6}, \mathrm{Li}_{3} \mathrm{AlF}_{6}, \mathrm{~K}_{3} \mathrm{AlF}\right)_{6}\right)$. In a melt with excess $\mathrm{AlX}_{3}$ (more $\mathrm{AlX}_{3}$ than what corresponds to cryolite), the composition displacement at the cathode may give lower actual temperature than liquidus temperature, which entails freezing of electrolyte at the cathode as illustrated in Figure 6(a)). It is possible that such freezing takes place in cells for primary aluminum production. ${ }^{[8]}$ If the melt contains excess $\mathrm{MX}\left(\mathrm{MX} / \mathrm{AlX}_{3}\right.$ ratio $>3$ ), freezing may take place at the anode. To prevent freezing, the electrolyte temperature should be above the highest liquidus temperature in the system.

Increased electrolyte density close to the electrodes should be avoided, at least in a cell with little convection, since it will lead to stratification and build-up of higher density electrolyte, e.g., in the anode chamber shown in Figure 5(b)). By keeping the composition close to the cryolite composition, the transport processes close to the electrodes give less dense electrolyte locally, which entails natural convection and less build-up of concentration gradients and concentration overvoltages.

It is known from primary aluminum production that the current efficiency decreases with increasing temperature. The temperature should, therefore, be kept as low as possible. The lowest possible temperature in $\mathrm{Na}_{3} \mathrm{AlF}_{6}-\mathrm{Li}_{3} \mathrm{AlF}_{6}$ is about $720{ }^{\circ} \mathrm{C} .{ }^{[9]}$ Lithium salts should be present to ensure high electrical conductivity. $\mathrm{Na}_{3} \mathrm{AlF}_{6}$ (and $\mathrm{K}_{3} \mathrm{AlF}_{6}$ ) have high oxide solubility. Possibly, the concentration of $\mathrm{Na}_{3} \mathrm{AlF}_{6}$ should be limited, in order to enable the use of oxides as cell lining material. The use of chloride in addition to fluoride also serves to lower the oxide solubility. Besides rendering possible the use of oxidic lining materials, a pure chloride melt would be water soluble, which makes regeneration of the electrolyte and separation of salts more manageable. The vapor pressure of the electrolyte would be relatively high, however. Chlorides no not form cryolite, but it is possible to obtain very low liquidus temperature. The electrolyte composition used in experiment $\mathrm{C}$ (Table 1) appears to be a good starting point for further development.

\section{Other Uses}

The cell concept sketched in Figure 5 may have other uses than recycling of aluminum. The design is generic, and it can be used for refining or recycling of any metal containing more noble elements. In some cases, the anode product will be more interesting, as the less noble (and less valuable) element dissolves from the anode compartment. In aluminum recycling, the anode product itself may be treated to separate out valuable metals.

As an example, it may be possible to produce pure scandium or a Sc-rich Al-Sc alloy. In this case, Sc will be dissolved at the anode and collected in the cathode chamber. The high melting point of Sc $\left(1541{ }^{\circ} \mathrm{C}\right)$ may represent a material challenge (unless the pure Sc can be collected as a solid).

A three-layer refining process for silicon has already been patented, ${ }^{[10]}$ but it is currently not being used industrially. The side-by-side arrangement may render possible a whole range of alternative electrolytes, since the density requirements are lifted.

\section{ACKNOWLEDGMENT}

The ICP analyses were performed by SINTEF Molab, Porsgrunn, Norway. The selection of aluminum alloy for treatment was based on discussions with Trond Bergstrøm, SINTEF.

\section{FUNDING}

Open access funding provided by SINTEF AS. 


\section{OPEN ACCESS}

This article is licensed under a Creative Commons Attribution 4.0 International License, which permits use, sharing, adaptation, distribution and reproduction in any medium or format, as long as you give appropriate credit to the original author(s) and the source, provide a link to the Creative Commons licence, and indicate if changes were made. The images or other third party material in this article are included in the article's Creative Commons licence, unless indicated otherwise in a credit line to the material. If material is not included in the article's Creative Commons licence and your intended use is not permitted by statutory regulation or exceeds the permitted use, you will need to obtain permission directly from the copyright holder. To view a copy of this licence, visit http://creativec ommons.org/licenses/by/4.0/.

\section{REFERENCES}

1. World Aluminium: http://www.world-aluminium.org/statistics/pri mary-aluminium-smelting-energy-intensity/\#data.

2. European Aluminium Association: https://european-aluminium.e u/media/1712/ea_recycling-brochure-2016.pdf.

3. World Aluminium: http://www.world-aluminium.org/statistics/ma ssflow/.

4. The Aluminium Automotive Manual:https://www.european-alumi nium.eu/media/1583/aam-applications-power-train-7-heat-exchan gers.pdf.

5. O.S. Kjos, S. Rolseth, H. Gudbrandsen, E. Skybakmoen, A. Solheim, and T.H. Bergstrøm: Proc. TMS-AIME, REWAS 2016, pp. 247-52.

6. P. Fellner, J. Híveš, and J. Thonstad: Proc. TMS-AIME, Light Metals 2011, pp. 513-16.

7. W. Hoopes, F.C. Frary, and J.D. Edwards: US patent No. 1534 318, April, 1925.

8. A. Solheim: Proc. TMS-AIME, Light Metals 2002, pp. 225-30.

9. J.L. Holm and B.J. Holm: Acta ChemScand., 1970, vol. 24 (7), pp. 2535-45.

10. E. Olsen, International Patent No. WO 2008/115072 A.

Publisher's Note Springer Nature remains neutral with regard to jurisdictional claims in published maps and institutional affiliations. 